\title{
Т.А. Танкиева
}

ФГБОУ ВО «Тульский государственный университет», Тула

М.В. Пономарева

ФГБОУ ВО «Тульский государственный университет», Тула

\section{Исследование предпочтений потребителей и проблем развития промышленного туризма в старопромышленном регионе (на примере Тульской области) ${ }^{1}$}

\begin{abstract}
Аннотация. В последние десятилетия растет интерес к промышленному туризму как способу диверсификации региональных экономик и одному из инструментов развития территорий. Теоретическое исследование на основе анализа научной литературы и имеющихся предложений показало, что индустриальный туризм получил распространение на ограниченных видах промышленных объектов - электростанциях и производствах, выпускающих пищевую продукцию или привлекательные для потребителей товары (сувениры, игрушки, автомобили). Органы государственного управления и местного самоуправления могут стимулировать развитие промышленного туризма в регионе, используя потенциал соответствующих предприятий, составляющих его основную экономическую базу. Необходима гибкая поддержка предприятий со стороны других акторов туризма в зависимости от уровня заинтересованности производств и возможных выгод для региона. Помощь в формировании современных турпродуктов и разработки эффективных маркетинговых стратегий может быть оказана научным потенциалом местных учебных заведений. Практическую значимость работы представляют результаты опроса 564 потенциальных потребителей промышленного туризма, которые выявили значительные различия в интересе туристов к организации и наполнению программ в зависимости от пола и возраста респондентов.
\end{abstract}

Ключевые слова: промышленный туризм, индустриальный туризм, потребители туризма, диверсификаиия деятельности, потенииал региона, промышленнал экскурсия.

Классификация JEL: M30, R11.

DOI: $10.31737 / 2221-2264-2021-49-1-6$

\section{1. Введение}

Автоматизация и роботизация производственных процессов приводит к высвобождению рабочей силы с промышленных предприятий, к изменению экономической базы городов, в результате чего все большая часть населения находит занятость в сфере услуг. Производства и объекты промышленного наследия обладают высоким туристическим потенциалом, а туризм, благодаря мультипликативному әффекту, предоставляет большие возможности для создания рабочих мест.

В настоящее время интерес к промышленному (индустриальному $)^{2}$ туризму растет по всему миру. Рост спроса на индустриальный туризм привел к тому, что в ряде стран (Франции, Испании, Португалии) были разработаны и внедрены стандарты в области качества обслужива-

\footnotetext{
${ }^{1}$ Исследование выполнено при финансовой поддержке Российского фонда фундаментальных исследований и Тульской области (проект 19-410-710004).

2 Здесь и далее по тексту выражения «индустриальный туризм» и «промышленный туризм» используются авторами как равнозначные.
} 
ния, а в 2015 г. был введен международный стандарт ISO 13810 Tourism services - Industrial tourism - Service provision, на основе которого был утвержден идентичный стандарт в РФ - ГОСТ Р ИСО 13810-2016 «Туристские услуги. Промышленный туризм. Предоставление услуг». В стандарте «Промышленный туризм» (industrial tourism) рассматривается как посещение действующих предприятий (living industry) и объектов промышленного наследия (industrial heritage). Многие регионы Российской Федерации имеют условия для развития обоих направлений промышленного туризма. В данной статье рассмотрено направление действующих предприятий (living industry), т.е. посещение действующих предприятий.

\section{2. Обзор состояния вопроса}

Изменение экономической базы в условиях новой индустриализации и глобализации, высокая конкуренция территорий за ресурсы, посетителей и инвестиции привели к поиску новых путей развития регионов. Многие промышленные города превратились в туристические центры или рассматривают туризм как возможность диверсификации экономики, повышения занятости населения, снятия социальной напряженности и пр. Результаты исследований, приведенные в отечественной и зарубежной научной литературе, показывают, что развитие промышленного туризма может приносить выгоды не только предприятиям, но и территориям (табл. 1).

\section{Таблица 1}

Выгоды от развития промышленного туризма для территорий

\begin{tabular}{|l|l|}
\hline \multicolumn{1}{|c|}{ Выгода } & \multicolumn{1}{|c|}{ Источники } \\
\hline \hline $\begin{array}{l}\text { Диверсификация деятельности кризисных регио- } \\
\text { нов и предприятий }\end{array}$ & $\begin{array}{l}\text { Гарнов, Краснобаева, 2012; } \\
\text { Cordeiro, 2017; Gelbman, 2007 }\end{array}$ \\
\hline $\begin{array}{l}\text { Создание дополнительных рабочих мест, решение } \\
\text { проблем острой безработицы в регионах с узкой } \\
\text { производственной специализацией }\end{array}$ & $\begin{array}{l}\text { Гарнов, Краснобаева, 2012; } \\
\text { Cordeiro, 2017 }\end{array}$ \\
\hline $\begin{array}{l}\text { Приток денежных средств в регионы и на отдель- } \\
\text { ные производства }\end{array}$ & $\begin{array}{l}\text { Гарнов, Краснобаева, 2012; } \\
\text { Otgaar, 2012; Скляренко и др., 2011; } \\
\text { Тимофеев, 2014; Яшалова и др., 2017 }\end{array}$ \\
\hline $\begin{array}{l}\text { Продвижение старопромышленных и промыш- } \\
\text { ленно развитых регионов }\end{array}$ & $\begin{array}{l}\text { Власова, Голубчиков, Курилова, 2018; } \\
\text { Оtgaаг, 2012; Сһош еt al., 2017; Яшалова } \\
\text { и др., 2017 }\end{array}$ \\
\hline $\begin{array}{l}\text { Повышение интереса школьников и молодежи } \\
\text { к инженерным специальностям }\end{array}$ & $\begin{array}{l}\text { Гарнов, Краснобаева, 2012; Соломонова, } \\
\text { Нарута, 2018; Никулина, 2015 }\end{array}$ \\
\hline $\begin{array}{l}\text { Әффективное использование территорий и объ- } \\
\text { ектов страны в целях устойчивого развития }\end{array}$ & $\begin{array}{l}\text { Гарнов, Краснобаева, 2012; Сordeiro, } \\
2017 ; \text { Gelbman, 2007; Тимофеев, 2014; } \\
\text { Яшалова и др., 2017 }\end{array}$ \\
\hline $\begin{array}{l}\text { Снижение социального напряжения путем демон- } \\
\text { страции экологической и техногенной безопасно- } \\
\text { сти действующих производств }\end{array}$ & $\begin{array}{l}\text { Гарнов, Краснобаева, 2012; Gelbman, } \\
2007\end{array}$ \\
\hline $\begin{array}{l}\text { Косвенное стимулирование развития сопутствую- } \\
\text { щей туристической инфраструктуры }\end{array}$ & $\begin{array}{l}\text { Гарнов, Краснобаева, 2012; Соrdеiro, } \\
2017\end{array}$ \\
\hline
\end{tabular}

Источник: составлено авторами. 
Промышленный туризм рассматривается не только как источник дополнительных доходов, но и как инструмент маркетинга или брендинга промышленно развитых территорий. С позиций экономической выгоды развитие индустриального туризма особенно важно для старопромышленных регионов и моногородов, которые, обладая ограниченными ресурсами, имеют действующие производства или объекты индустриального наследия, интересные потребителю. Однако имеющийся потенциал далеко не всегда удается реализовать. Основными препятствиями для развития промышленного туризма являются факторы:

- закрытость предприятий, связанная с защитой коммерческой тайны (Гарнов, Краснобаева, 2012; Никулина, 2017; Богомолова, Танкиева, Пономарева, 2018; Власова, Голубчиков, Курилова, 2018);

- недоценка наличия спроса на подобные услуги представителями производств (Гарнов, Краснобаева, 2012; Никулина, 2017; Богомолова, Танкиева, Пономарева, 2018; Яшалова и др., 2017);

- сложности в организации экскурсий, планировании маршрутов и обеспечении безопасности (Lee C.-F., 2015; Никулина, 2017; Глаголева и др., 2018);

- отсутствие кооперации между местными органами власти, руководителями предприятий и туристическими компаниями (Гарнов, Краснобаева, 2012; Глаголева и др., 2018);

- отсутствие ресурсов и возможностей для продвижения промышленного туризма (Гарнов, Краснобаева, 2012; Власова, Голубчиков, Курилова, 2018; Глаголева и др., 2018; Яшалова и др., 2017);

- низкая транспортная доступность (Гарнов, Краснобаева, 2012);

- отсутствие вспомогательной инфраструктуры - бюджетных гостиниц, предприятий питания и т.д. (Гарнов, Краснобаева, 2012).

Национальный туристический портал Russia.travel Федерального агентства по туризму Министерства экономического развития Р $\Phi^{3}$ содержит 103 индустриальных объекта, на которые осуществляются экскурсии. Эта цифра гораздо меньше, чем число предприятий, принимающих экскурсантов и туристов в стране. Несмотря на разнообразие объектов (от космодрома до водяных мельниц), большая часть производств на портале представляет электростанции, в основном ГӘС $(24 \%)$, гидротехнические сооружения $(9 \%)$, а также пищевые производства $(15 \%)$ - пивоваренные заводы, кондитерские фабрики и хладокомбинаты. На международном портале Man-MadeWorld главным образом представлены туры на пищевые производства (винодельни, кондитерские фабрики, хладокомбинаты и пивоварни) и предприятия автомобильной промышленности. Результаты анализа отечественных и зарубежных научных источников также свидетельствуют, что

3 “Путеводитель / Индустриальные объекты». Национальный туристический портал Russia.travel (https:// russia.travel $/$ guide $/$ ?types $=440$ ). 
индустриальный туризм в основном развит на следующих видах производств: предприятиях пищевой промышленности; предприятиях, производящих привлекательные для потребителей товары (сувениры, игрушки, автомобили), и предприятиях по производству электроэнергии. В меньшей степени такой вид представлен турами на химические, машиностроительные (кроме предприятий автомобильной промышленности) и металлургические производства. На предприятиях постсоветского пространства характерно наличие музеев при производствах.

Производства чаще всего имеют следующие преференции, которые может предоставить прием экскурсантов:

- экономическая выгода - диверсификация основного бизнеса за счет реализации экскурсионных услуг, услуг питания, дополнительных услуг (мастер-классы, интерактивные программы), возможности продажи товара и сувенирной продукции;

- связь с общественностью - демонстрация экологической, техногенной безопасности производства, повышение осведомленности о вкладе предприятия в экономику региона и страны;

- маркетинг - увеличение потребительского потенциала продукции, коммуникация «из уст в уста», возможность иметь обратную связь с потребителем, возможность изучать новые рынки и тестировать новую продукцию;

- деловой туризм - демонстрация производства с целью поиска деловых партнеров;

- профориентация - получение мотивированных кадров для производства.

Ввиду разной заинтересованности предприятий в посещении экскурсантами наблюдаются ситуации и когда организация программ промышленного туризма осуществляется самостоятельно самими предприятиями, и когда предоставление таких услуг стимулируется другими акторами - в первую очередь городскими и государственными органами власти. Примером стимулирования развития туризма властями может служить Роттердам, где был учрежден специальный фонд промышленного туризма при финансовой поддержке правительства Нидерландов, в частности для поощрения посещения порта. Другой пример - проект «Взгляд в промышленность» местного совета в Чешире, стартовавший с 12 компаниями в 1987 г. и объединяющий более 100 предприятий в настоящее время (Gelbman, 2007): судоремонтные и судостроительные предприятия, бумажные фабрики, производителей автомобилей, горюче-смазочных материалов и тяжелой промышленности, а также предприятия малого бизнеса. В Российской Федерации промышленный туризм как одно из возможных направлений экономического развития регионов стал рассматриваться недавно. В 2017 г. Федеральным агентством по туризму при участии Уральской ассоциации туризма был учрежден «Совет по развитию промышленного туризма» с целью эффективного использования индустриального наследия и промыш- 
ленных объектов, координации действий представителей отраслевых министерств, региональных властей, промышленных предприятий регионов и общественных объединений. Основными направлениями деятельности совета являются:

- разработка предложений по внесению изменений в нормативно-правовые акты, регламентирующих и упрощающих систему допуска туристов на объекты добычи и режимные промышленные предприятия;

- издание специализированной методической литературы по вопросам стандартов промышленного туризма в Российской Федерации;

- продвижение промышленного туризма на внутренних и международных площадках;

- просветительская деятельность, организация круглых столов, конференций и пр.;

- создание единой карты промышленного туризма в России.

Большая часть старопромышленных регионов России имеют ресурсы, представленные предприятиями машиностроения, химической, горнодобывающей промышленности и металлургическими производствами. К основным акторам промышленного туризма в Российской Федерации, помимо региональных и государственных органов власти, промышленных предприятий, населения и общественных организаций, учреждений культуры, представителей туристического бизнеса (Власова, Голубчиков, Курилова, 2018), относятся и образовательные учреждения (Никулина, 2015). Экскурсии на промышленные предприятия могут способствовать освоению компетенций в области профессиональной деятельности для студентов высшего и среднего профессионального образования или использоваться для организации профориентационной и внеурочной деятельности школьников.

Научная литература, рассматривающая промышленный туризм как направление экономического развития и городского планирования, только формируется. В основном научные работы содержат описание практик организации туризма в регионах и посещения конкретных типов производств; слабо исследованы потребители промышленного туризма (Otgaar, 2012). В таких исследованиях анализировался интерес у потенциальных потребителей и внутреннего спроса в регионе (Никулина, 2017; Богомолова, Танкиева, Пономарева, 2018; Кадыров, Мударисов, 2018), однако этот анализ опирается на маленькие выборки от 50 до 192 человек. Изучение потребителей важно для разработки конкурентоспособного туристического продукта и формирования устойчивого спроса на него, так как посещение предприятий осуществляется преимущественно организованными группами. Аспекты, связанные с предприятиями, проработаны в направлении изучения востребованности и перспектив развития услуг промышленного туризма, например в работах (Никулина, 2015, 2017). 
Недостаточно изучены проблемы организации туристической деятельности на производствах.

\section{3. Данные и методы исследования}

Исследование предпочтений потребителей промышленного туризма и основных аспектов организации туризма на производствах проводилось в Тульской области, которая была выбрана как старопромышленный регион, в котором доля обрабатывающей промышленности в суммарном объеме ВРП занимает около 40\%. Среди ключевых отраслей региона преобладают машиностроение, ОПК, химическая промышленность и металлургия. В регионе также представлена добывающая промышленность, сувенирное производство, имеются крупные пищевые производства. Область обладает рядом таких известных брендов, представляющих разные виды производств, как тульский пряник и белевская пастила, самовары, тульская гармонь, тульское стрелковое оружие и системы залпового огня. Как и в других субъектах РФ, туристы организованно посещают предприятия пищевой промышленности и сувенирные производства.

Исходные данные для исследования были получены в ходе опроса организаторов туризма, представителей предприятий региона и анкетирования потенциальных потребителей промышленного туризма.

\section{4. Исследование предпочтений потребителей}

С целью изучения предпочтений потенциальных потребителей промышленного туризма в мае 2019 г. проводился анкетный опрос. Предварительно для выявления круга основных вопросов, касающихся промышленного туризма, а также уточнения их возможных формулировок, было проведено глубинное интервью лиц, имеющих опыт в организации промышленного туризма, и опрос жителей и гостей Тульской области. Далее с помощью волонтеров среди гостей и жителей Тульской области было распространено 700 экземпляров разработанной по результатам предварительного этапа анкеты. В итоге в опросе приняли участие 564 человека (72\% жителей и $28 \%$ гостей Тульской области) в возрасте от 14 лет до 81 года. Доверительная вероятность проведенного исследования для жителей области составила $95 \%$ при доверительном интервале в 5\%, а для посетителей - 93\% $7 \%$. Большую часть анкетируемых составили женщины (60,5\%). Распределение по полу и возрастным группам респондентов представлено в табл. 2.

Данные анкетирования обрабатывались с помощью методов описательной статистики и корреляционного анализа.

Анкетирование потенциальных потребителей промышленного туризма выявило существенные отличия в ответах респондентов в зависимости от пола, поэтому результаты исследования по каждому вопросу обрабатывались отдельно для мужчин и женщин. Общий результат при 
таблица 2

Структура выборочной совокупности респондентов исследования

\begin{tabular}{|c|c|c|l|c|c|c|}
\hline $\begin{array}{c}\text { Возраст, } \\
\text { лет }\end{array}$ & $\begin{array}{c}\text { Численность, } \\
\text { человек }\end{array}$ & $\%$ & $\begin{array}{c}\text { Мужчины, } \\
\text { человек }\end{array}$ & $\begin{array}{c}\text { Мужчины, } \\
\%\end{array}$ & $\begin{array}{c}\text { Женщины, } \\
\text { человек }\end{array}$ & $\begin{array}{c}\text { Женщины, } \\
\%\end{array}$ \\
\hline \hline$<23$ & 109 & 19,3 & 36 & 6,4 & 73 & 12,9 \\
\hline $23-35$ & 235 & 41,7 & 107 & 19,0 & 128 & 22,7 \\
\hline $36-50$ & 148 & 26,2 & 49 & 8,7 & 99 & 17,6 \\
\hline$>50$ & 72 & 12,8 & 31 & 5,5 & 41 & 7,3 \\
\hline Всего & 564 & 100 & 223 & 39,5 & 341 & 60,5 \\
\hline
\end{tabular}

Источник: составлено авторами.

необходимости вычислялся как среднее значение между их выбором. Такая обработка также позволила снизить погрешность исследования в связи с преобладанием женщин среди опрошенных.

На вопрос «Посещение какого производства вас интересует больше всего?» анкетируемым было предложено выбрать три типа предприятия (производства) из предложенных, проставив приоритет от 1 (больше всего интересует) до 3 (интересует меньше) (рис. 1), или вписать свой вариант. Баллы по каждой предложенной категории начислялись в зависимости от приоритета: 3 балла за «больше всего интересует», 2 балла за «интересует» и 1 балл за «интересует меньше».

Как показало исследование, оценка в баллах отражает процент выбранных ответов без учета приоритета посещения, так как предпри-

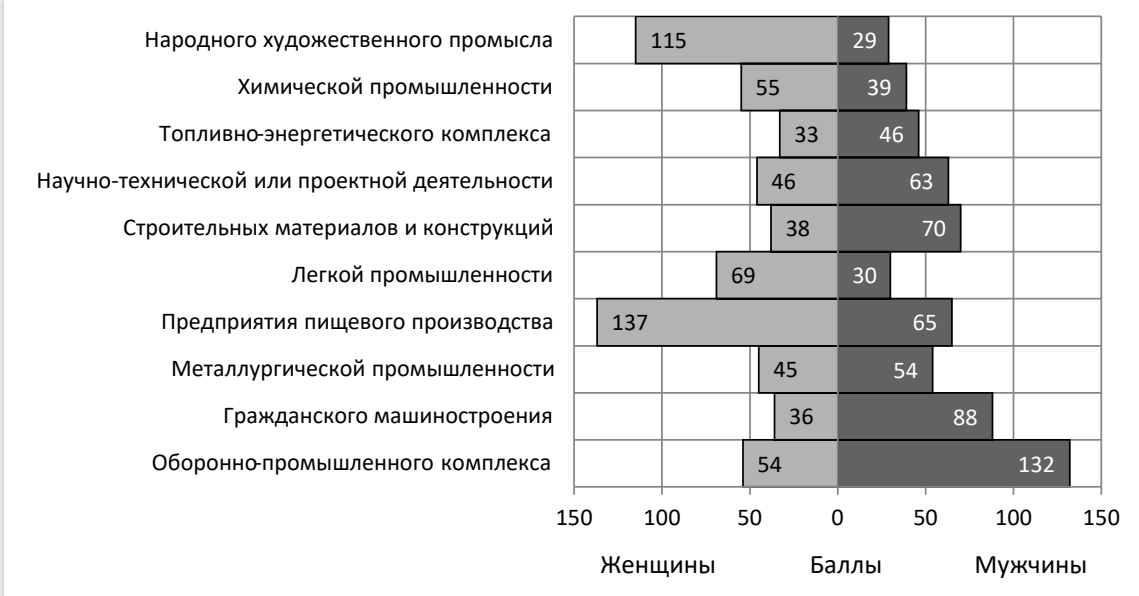

Puc. 1

Результаты ответа на вопрос «Посещение какого производства вас интересует больше всего?»

Источник: составлено авторами. 
ятия, которым ставили выше приоритет, и выбирали чаще. Большую часть респондентов мужского пола интересует посещение предприятий ОПК (55\%), гражданского машиностроения (44\%), строительных материалов и конструкций (36\%), пищевого производства и предприятий научно-технической деятельности (по 33\%). У лиц женского пола в первую очередь вызывают интерес предприятия пищевого производства $(62 \%)$, народного художественного промысла $(54 \%)$, легкой $(40 \%)$, химической (28\%) промышленности и ОПК (26\%). Посетителей Тульской области предприятия ОПК, гражданского машиностроения и народного художественного промысла интересуют в большей степени, чем туляков, но в целом предпочтения близкие - корреляция составляет 0,79. Возможностью вписать в анкеты свой вариант жители и гости Тульской области не воспользовались.

На вопрос «Интересует ли вас посещение следующих предприятий?» с возможностью выбрать из предложенных вариантов ответа или предложить свой большая часть респондентов выбрала Тульский оружейный завод (у мужчин 69\%, у женщин 54\%) (рис. 2, 3). Женщины хотели бы посетить производства тульских пряников (59\%), кондитерскую фабрику «Ясная Поляна» (57\%), машиностроительный завод «Штамп» им. Б.Л. Ванникова (54\%) (производство тульских самоваров) и Тульский молочный комбинат. Респондентов мужского пола интересуют посещение Тульского машиностроительного завода $(44 \%)$, «Тулачермет» $(44 \%)$ и пивоваренного завода «Балтика» $(43 \%)$. Анкетируемые предложили только три варианта предприятий, которые бы они хотели посетить: Конструкторское бюро приборостроения им. академика А.Г. Шипунова, тульскую обувную фабрику «Заря» и Тульский мясокомбинат. Как можно увидеть на рис. 3, предприятия вызывают схожий интерес как у гостей Тульской области, так и у жителей края: коэффициент корреляции между данными группами респондентов составляет 0,955 .

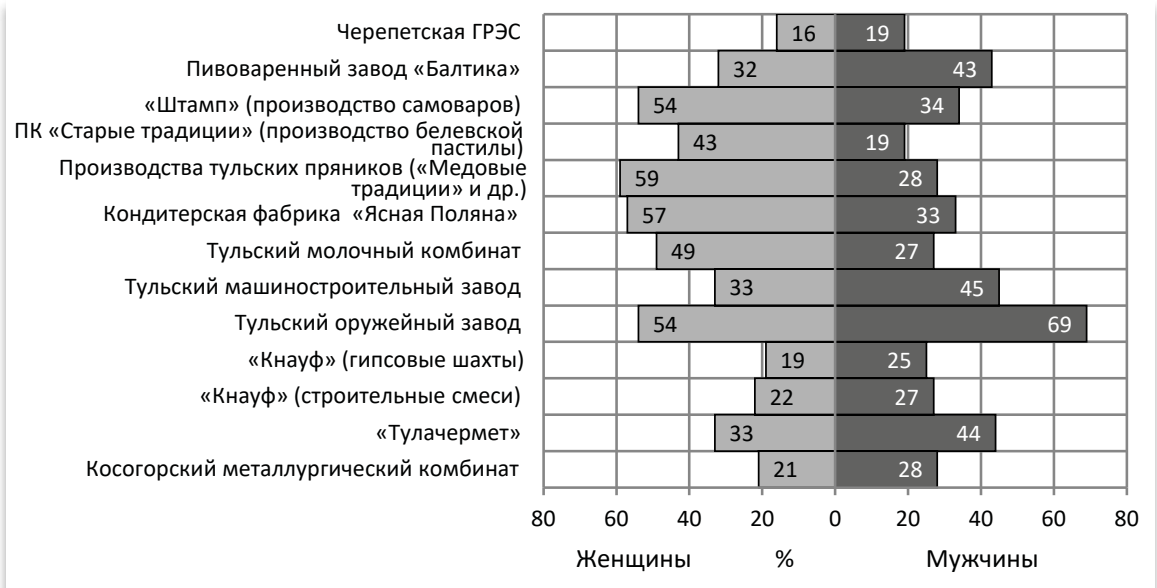

Puc. 2

Результаты ответа на вопрос "Интересует ли вас посещение следующих предприятий?»

Источник: составлено авторами. 


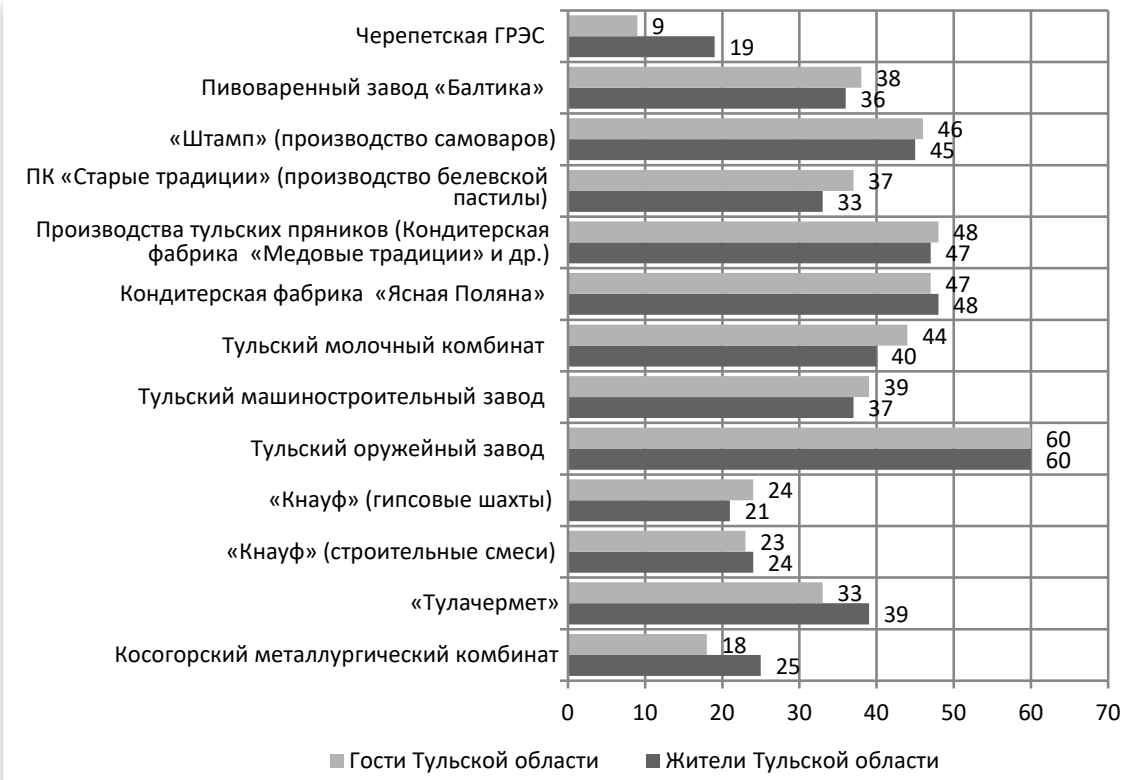

Puc. 3

Результаты ответа на вопрос «Интересует ли вас посещение следующих предприятий?» ужителей и гостей Тульской области

Источник: составлено авторами.

Большая часть гостей области $(60 \%)$ хотела бы посетить Тульский оружейный завод. Данный интерес может быть обусловлен тем, что предприятие является старейшим оружейным заводом на территории РФ и воспринимается как визитная карточка края. Кроме того, посетители выбрали производства, связанные с такими брендами края, как тульский пряник и тульский самовар. Производство тульских гармоней интересует жителей и гостей Тульской области в гораздо менышей степени $-24 \%$, по данным предварительного исследования (в основное исследование объект включен не был).

Анализ ответов респондентов на вопрос «Что вас больше всего интересовало бы при посещении химических, металлургических производств, предприятий топливно-энергетического комплекса и предприятий по производству строительных материалов?» с возможностью множественного выбора выявил существенное отличие в ответах как в зависимости от возраста участников, так и в зависимости от пола (табл. 3). Мужчин интересует в основном оборудование $(59 \%)$ и технологический процесс $(50 \%)$; другие варианты они выбирали значительно реже. Женщин меньше интересуют предприятия такого типа (см. рис. 1, 2), они интересуются приблизительно в равной степени соблюдением экологической безопасности производства, возможностью убедиться в качестве продукции, технологическим процессом, оборудованием и возможностью сделать интересные фотографии. 
таблица 3

Ответы респондентов на вопрос «Что вас больше всего интересовало бы при посещении химических, металлургических производств, предприятий топливно-энергетического комплекса и предприятий по производству строительных материалов?»

\begin{tabular}{|l|c|c|c|c|c|c|c|c|c|c|}
\hline \multirow{2}{*}{ Вариант ответа } & \multicolumn{5}{|c|}{ Мужчины, возраст } & \multicolumn{5}{c|}{ Женщины, возраст } \\
\cline { 2 - 13 } & $<23$ & $23-35$ & $36-50$ & $>50$ & $\bar{X}$ & $<23$ & $23-35$ & $36-50$ & $>50$ & $\bar{X}$ \\
\hline \hline $\begin{array}{l}\text { Технологический про- } \\
\text { цесс, \% }\end{array}$ & 36 & 61 & 57 & 45 & 50 & 40 & 38 & 34 & 20 & 33 \\
\hline Оборудование, \% & 61 & 50 & 55 & 68 & 59 & 44 & 38 & 20 & 34 & 34 \\
\hline $\begin{array}{l}\text { Соблюдение экологиче- } \\
\text { ской безопасности, \% }\end{array}$ & 25 & 19 & 18 & 39 & 25 & 33 & 31 & 44 & 56 & 41 \\
\hline $\begin{array}{l}\text { Возможность сделать } \\
\text { интересные фотографии, } \\
\%\end{array}$ & 28 & 25 & 12 & 10 & 19 & 44 & 34 & 28 & 20 & 32 \\
\hline $\begin{array}{l}\text { Профессии и условия } \\
\text { труда, \% }\end{array}$ & 19 & 23 & 24 & 23 & 22 & 21 & 22 & 22 & 27 & 23 \\
\hline $\begin{array}{l}\text { Возможность убедиться } \\
\text { в качестве продукции, \% }\end{array}$ & 25 & 17 & 31 & 26 & 25 & 40 & 34 & 41 & 39 & 38 \\
\hline $\begin{array}{l}\text { Возможность ознако- } \\
\text { миться с историей произ- } \\
\text { водства, \% }\end{array}$ & 25 & 21 & 18 & 13 & 19 & 25 & 31 & 23 & 24 & 26 \\
\hline
\end{tabular}

Примечание. $\bar{X}$ - среднее арифметическое значение по варианту ответа.

Источник: составлено авторами.

Как показывают данные опроса, соблюдение экологической безопасности предприятиями химической, металлургической промышленности, топливно-энергетического комплекса или строительных материалов и конструкций в большей степени волнует лиц старшего возраста (мужчин старше 50 лет и женщин старше 35). Число выбранных вариантов «Возможность сделать интересные фотографии» обратно пропорционально возрасту респондентов и в 1,5-2 раза больше у женщин.

При посещении пищевого производства ключевыми интересами как для женщин, так и для мужчин является возможность убедиться в качестве продукции и возможность ее дегустации (рис. 4). Мастер-классы, интерактивные программы и рецептура в большей степени интересуют женщин. Технологический процесс производства пищевой продукции интересует оба пола примерно в равной степени.

У лиц мужского пола результаты ответа существенно зависят от возраста респондентов (рис. 5). Коэффициент корреляции 0,85 между вариантами «Возможность убедиться в качестве продукции» и «Технологический процесс» позволяет предположить, что с возрастом мужчины в понятие качества продукции вкладывают и определен- 
Мастер-классы и интерактивные программы

$$
\text { Дегустация продукции }
$$

Возможность ознакомиться с историей производства

Возможность убедиться в качестве продукции

Профессии и условия труда

Возможность сделать интересные фото

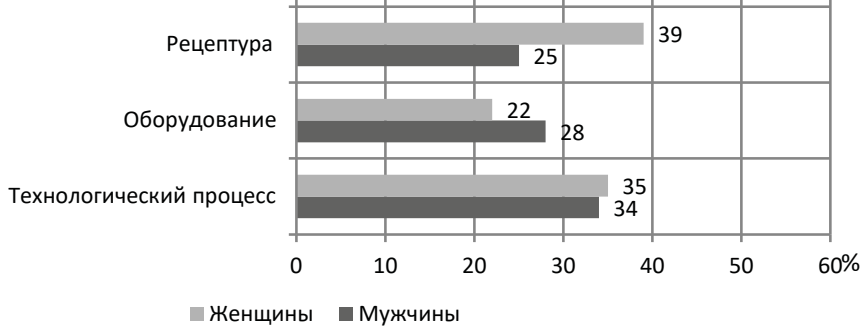

Рис. 4

Результаты ответа на вопрос «Что вас больше всего интересовало бы при посещении пищевого производства?»

Источник: составлено авторами.

ную технологию производства. У женщин интерес к технологии производства с возрастом меняется в незначительных пределах (32-37\%) и не имеет корреляции с числом выбранного варианта ответа относительно качества продукции.

Результаты ответа на вопрос «Какие ассоциации у вас вызывает промышленный туризм?» с возможностью выбрать вариант ответа или предложить свой показывают, что ожидание познавательной составля-

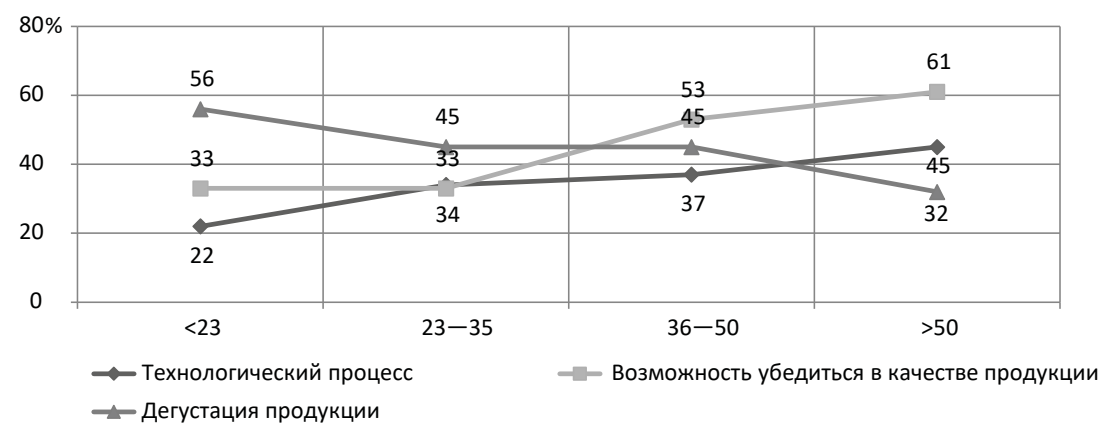

Puc. 5

Доля выбранных вариантов ответа среди мужиин (в зависимости от возраста) Источник: составлено авторами. 
таблица 4

Результаты ответа мужчин на вопрос «Какие ассоциации

у вас вызывает промышленный туризм?», \%

\begin{tabular}{|c|c|c|c|c|}
\hline Возраст & Познавательно & Интересно & Профориентация & Скучно \\
\hline \hline$<23$ & 28 & 39 & 31 & 19 \\
\hline $23-35$ & 32 & 46 & 25 & 11 \\
\hline $36-50$ & 47 & 39 & 20 & 10 \\
\hline$>50$ & 55 & 26 & 23 & 6 \\
\hline $\begin{array}{l}\text { Среднее арифметическое зна- } \\
\text { чение по варианту ответа }\end{array}$ & 40 & 37 & 25 & 12 \\
\hline
\end{tabular}

Источник: составлено авторами.

таблица 5

Результаты ответа женщин на вопрос «Какие ассоциации у вас вызывает промышленный туризм?», \%

\begin{tabular}{|c|c|c|c|c|}
\hline Возраст & Познавательно & Интересно & Профориентация & Скучно \\
\hline \hline$<23$ & 42 & 49 & 25 & 18 \\
\hline $23-35$ & 48 & 50 & 16 & 8 \\
\hline $36-50$ & 52 & 43 & 20 & 8 \\
\hline$>50$ & 59 & 44 & 12 & 7 \\
\hline $\begin{array}{c}\text { Среднее арифметическое значе- } \\
\text { ние по варианту ответа }\end{array}$ & 50 & 47 & 18 & 10 \\
\hline
\end{tabular}

Источник: составлено авторами.

ющей от услуги промышленного туризма существенно возрастает с возрастом респондентов (табл. 4, 5), особенно для мужчин. Возможностью вписать в анкеты свой вариант ответа респонденты не воспользовались.

Женщины готовы ознакомиться с производством машиностроительных, металлургических, химических и ОПК предприятий (оборудованием, технологией, историей и пр.) как через экскурсионные программы в музеях (51\%), так и при посещении самого производства (49\%), причем интерес к производственному процессу прямо пропорционален возрасту опрошенных. Мужчины в большей степени нацелены на ознакомление с технологией, оборудованием и производством непосредственно на предприятии $(81 \%)$.

\section{5. Проблемы развития промышленного туризма в Тульской области}

Несмотря на большое количество промышленных предприятий в регионе, только десять организаций области сотрудничают с туристическими компаниями и принимают туристов: шесть предприятий пищевого производства, фабрика «Тульская гармонь», рыбоводческое предприятие «Приокское», кирпичный завод «BRAER», Ефремовский 
завод синтетического каучука. Значительная часть производств сотрудничает с образовательными учреждениями края в рамках профориентационной работы, девять предприятий (включая три упомянутых выше предприятия), по данным Регионального центра содействия трудоустройству, делают это на постоянной основе и организуют посещение производств с другими целями. Ряд таких крупных производств, как «НАК “Азот” , Тульский кирпичный завод, «Проктер энд Гэмбл Новомосковск», «Полипласт Новомосковск», «Оргсинтез», предприятия компании ЕвроХим, «Кнауф Гипс Новомосковск», проводят экскурсии в рамках мероприятий общественного экологического контроля.

Для исследования проблем, связанных с организацией услуг промышленного туризма на предприятиях области, использовались методы индивидуальных экспертных оценок. В мае 2019 г. были проведены индивидуальные интервью с четырьмя экспертами, задействованными в организации посещений предприятий, - представителями туристических компаний и экскурсионных бюро с целью выявления предприятий, обладающих потенциалом для развития промышленного туризма в регионе, а также вскрытия проблем, связанных с организацией индустриального туризма и посещением производств в настоящее время.

С учетом данных, полученных в ходе интервью с экспертами, и результатов анкетного опроса потенциальных потребителей промышленного туризма в июне-июле 2019 г. был проведен опрос представителей перспективных для организации промышленного туризма предприятий ${ }^{4}$. Результаты опроса показали, что, в зависимости от типа производства, организации имеют разную степень заинтересованности в возможностях промышленного туризма (табл. 6).

\section{таблица 6}

Заинтересованность в предоставлении услуг промышленного туризма в зависимости от типа производства

\begin{tabular}{|l|l|c|}
\hline \multicolumn{1}{|c|}{ Тип производства } & Цели или возможный интерес & Заинтересованность \\
\hline \hline Сувенирное производство & $\begin{array}{l}\text { Получение дополнительных } \\
\text { основных доходов }\end{array}$ & Очень высока или высокая \\
\hline Пищевые производства & $\begin{array}{l}\text { Создание положительного } \\
\text { имиджа продукции (продви- } \\
\text { жение продукции), получение } \\
\text { дополнительных доходов }\end{array}$ & Высокая или средняя \\
\hline $\begin{array}{l}\text { Производства легкой } \\
\text { промышленности, пред- } \\
\text { приятия гражданского } \\
\text { машиностроения }\end{array}$ & $\begin{array}{l}\text { Создание положительного } \\
\text { имиджа продукции (продви- } \\
\text { жение продукции), деловой } \\
\text { туризм }\end{array}$ & \multicolumn{1}{c|}{ Средняя } \\
\hline
\end{tabular}

\footnotetext{
${ }^{4}$ Выборку исследования составили представители 4 сувенирных производств, 8 пищевых производств, 7 предприятий гражданского машиностроения (в том числе 2 предприятий тяжелого машиностроения), 9 предприятий ОПК различного профиля, 5 предприятий химической промышленности, 3 металлургических предприятий, 6 производств легкой промышленности, 3 производств строительных материалов (изделий) и строительных конструкций, 3 предприятий топливно-энергетического комплекса.
} 
Окончание таблицы 6

\begin{tabular}{|c|c|c|}
\hline Тип производства & Цели или возможный интерес & Заинтересованность \\
\hline $\begin{array}{l}\text { Производства химической } \\
\text { промышленности; производ- } \\
\text { ства строительных материа- } \\
\text { лов (изделий) и строительных } \\
\text { конструкций; металлургиче- } \\
\text { ское производство; предпри- } \\
\text { ятия топливно-энергетиче- } \\
\text { ского комплекса }\end{array}$ & $\begin{array}{l}\text { Создание положительного } \\
\text { имиджа производства, инфор- } \\
\text { мирование населения об } \\
\text { экологической безопасности } \\
\text { производства и мерах по пред- } \\
\text { упреждению техногенных } \\
\text { катастроф, профориентация, } \\
\text { деловой туризм }\end{array}$ & Низкая \\
\hline $\begin{array}{l}\text { Предприятия ОПК; пред- } \\
\text { приятия гражданского } \\
\text { машиностроения (тяжелое } \\
\text { машиностроение) }\end{array}$ & $\begin{array}{l}\text { Профориентация, деловой } \\
\text { туризм }\end{array}$ & Очень низкая \\
\hline
\end{tabular}

Источник: составлено авторами.

Наибольшую заинтересованность в промышленном туризме имеют сувенирные производства - при грамотной рыночной стратегии продаж доход от экскурсионных и сопутствующих услуг может превышать средства, полученные в ходе реализации основной продукции. Наименее заинтересованы в промышленном туризме предприятия химической промышленности, топливно-энергетического комплекса, производства строительных материалов (изделий) и строительных конструкций, металлургического производства, тяжелого машиностроения и ОПК. На предприятиях ОПК в связи с соблюдением коммерческой или государственной тайны экскурсии для широкого круга посетителей невозможны и проводятся только в рамках деловых визитов или профориентации. Тульский оружейный завод, НПО «Сплав», Конструкторское бюро приборостроения имени академика А. Г. Шипунова сотрудничают в Тульским государственным музеем оружия, парком «Патриот», Музеем станка, где можно ознакомиться с некоторыми видами продукции предприятий и историей производств. Предприятия остальных типов могут быть заинтересованы в создании положительного имиджа, информирования потребителей и местных жителей о вкладе организации в экономику региона и об экологической безопасности производства. Хорошим примером служит интерактивно-познавательный центр «Зеленая планета» АО «Апатит» группы Компаний «ФосАгро» в городе Череповец Вологодской области. Центр участвует в образовательных программах и в таких мероприятиях, как «Ночь в музее». В Тульской области примером такого предприятия является компания BRAER по высокотехнологическому производству кирпича и крупноформатного керамического блока.

Интервью, проведенное с организаторами туризма, выявило следующие проблемы:

- нежелание предприятий принимать туристов, даже если они заявляют о готовности их принимать;

- непонимание различий между туристом и покупателем (неболь- 
шие производства, в том числе пищевые, ждут покупателей, а не туристов);

- завышение цены на посещение или уверенность в том, что услуги промышленного туризма нерентабельны и требуют значительных временных и организационных затрат;

- невладение методикой планирования экскурсии и показа (зачастую маршрут необустроен, представители производств не умеют вести экскурсию);

- незнание национального стандарта ГОСТ Р ИСО 13810-2016 «Туристские услуги. Промышленный туризм. Предоставление услуг» (считают введение стандарта сдерживающим фактором для внедрения туристских услуг на предприятии).

Таким образом, организация промышленного туризма средствами самих предприятий на многих производствах без участия других акторов в настоящее время трудновыполнима или даже невозможна. Содействие должно быть оказано в первую очередь предприятиям, на которых возможен экскурсионный показ без нарушения коммерческой и/или государственной тайны и вызывающий наибольший интерес у потенциальных потребителей. Помощь в обследовании предприятий, формировании современных турпродуктов, исследовании рынка, разработки маркетинговых стратегий могут оказать учебные заведения регионов, где ведется подготовка специалистов в сфере экономики и сервиса. Для формирования устойчивого внутреннего спроса необходима поддержка министерств образования регионов, так как детский и юношеский туризм вносит существенный вклад в потребление экскурсионных услуг. Необходима разработка кейсов стандартизированных решений с проработкой юридических и организационных вопросов для разных видов производств. Юридическую поддержку и координирующую роль могут выполнять местные органы управления, например Комитет по развитию туризма Тульской области, который в настоящее время продвигает региональный турпродукт, в том числе представленный промышленным туризмом, на внешнем и внутреннем рынках.

\section{6. Заключение}

1. Потенциальные потребители услуг индустриального туризма имеют, в зависимости от пола, разные предпочтения как в отношении посещения определенных типов предприятий, так и в отношении того, что представляет для них интерес на производствах. В большей степени разность в интересах потребителей характерна для химических, металлургических предприятий, предприятий топливно-энергетического комплекса и производств строительных материалов (изделий) и строительных конструкций, что создает дополнительные трудности в организации туров с учетом низкой мотивации самих производств такого типа. При посещении пищевых производств как женщин, так и мужчин интересует возможность дегустировать продукцию и возможность 
убедиться в ее качестве. Рецептура, мастер-классы и интерактивные экскурсии, входящие в программы посещения пищевых производств, вызывают интерес в основном у женщин.

2. Производства брендовых товаров (продукции) и предприятия, составляющие имидж региона, пользуются одинаково высоким спросом как у внешнего, так и внутреннего потребителя и вызывают схожий интерес у мужчин и женщин.

3. Анализ предложений национального туристического портала Russia.travel Федерального агентства по туризму Министерства экономического развития РФ и выборочный опрос предприятий Тульской области показал, что в зависимости от типа производства предприятия имеют разную степень заинтересованности в предоставлении услуг промышленного туризма. Наиболее заинтересованы в промышленном туризме сувенирные, пищевые производства и предприятия, производящие привлекательные для потребителей товары. Наименее заинтересованы предприятия ОПК, тяжелого машиностроения, металлургической, химической промышленности и производства строительных материалов (изделий) и строительных конструкций. Ряд предприятий могут выступать организаторами туризма в рамках формирования положительного имиджа, информирования потребителей и местных жителей о вкладе в экономику региона, о мерах, направленных на предотвращение техногенных катастроф и на укрепление экологической безопасности производства.

4. Органы государственного управления и местного самоуправления могут стимулировать развитие промышленного туризма в регионах. Необходима гибкая поддержка предприятий со стороны других акторов туризма в зависимости от степени заинтересованности производств и возможных выгод для региона. Помощь в формировании современных турпродуктов и разработке эффективных маркетинговых стратегий могут предоставить учебные заведения регионов. Одним из направлений деятельности, связанной с развитием промышленного туризма, может быть разработка кейсов, содержащих проработку управленческих и юридических вопросов, а также с организацией посещения конкретных типов предприятий.

\section{ЛИТЕРАТУРА / REFERENCES}

Богомолова К.О., Танкиева Т.А., Пономарева М.В. (2018). Развитие промышленного туризма в Тульской области / / Сервис в России и за рубежом. Т. 12. № 3. C. 63-78. DOI: 10.24411/1995-042X-2018-10305 [Bogomolova K.O., Tankieva T.A., Ponomareva M.V. (2018). The industrial tourism development in Tula Region. Services in Russia and Abroad, 12 (3), 63-78. DOI: 10.24411/1995-042X-2018-10305 (in Russian).]

Власова Н.Ю., Голубчиков О.Ю., Курилова Е.В. (2017). Индустриальный туризм в продвижении старопромышленных регионов // Известия УрГЭУ. № 4 (72). C. 19-31. DOI: 10.29141/2073-1019-2017-16-4-2 [Vlasova N.Yu., 
Golubchikov O.Yu., Kurilova Ye.V. (2017). Industrial tourism in the old industrial regions promotion. Journal of New Economy, 4 (72), 19-31 (in Russian).]

Гарнов А.П., Краснобаева О.В. (2012). Актуальность системного формирования отечественного промышленного туризма / / Вестник РЭА им. Г.В. Плеханова. № 2. C. 60-63. [Garnov A.P., Krasnobaeva O.V. (2012). The relevance of the systemic formation of the domestic industrial tourism. Vestnik of the Plekhanov Russian University of Economics, 2, 60-63 (in Russian).]

Глаголева Л.Э., Куксова И.В., Валушкина В.А., Верейкина Е.С., Володина Е.Г., Соломахина Е.А. (2018). Формирование модели стратегического управления развитием промышленного туризма в регионе // Вестник ВГУИТ. Т. 80. № 1. C. 308-313. DOI: 10.20914/2310-1202-2018-1308-313 [Glagoleva L.E., Kuksova I.V., Valushkina V.A., Vereikina E.C., Volodina E.G., Solomakhina E.A. (2018). Formation of a model of strategic management of industrial tourism development in the region. Proceedings of the Voronezh State University of Engineering Technologies, 1 (80), 308-313. DOI: 10.20914/2310-1202-2018-1-308-313 (in Russian).]

Кадыров Р.В., Мударисов Р.Г. (2018). Промышленный туризм как креативный маркетинг // Вестник Алтайской академии экономики и права. № 8. C. 88-94. [Kadyrov R.V., Mudarisov R.G. (2018). Industrial tourism as creative marketing. Bulletin of the Altai Academy of Economics and Law, 8, 88-94 (in Russian).]

Клейменова Е.О., Чулакова А.О. (2014). Диверсификация экономики моногородов за счет развития промышленного туризма // Инфраструктурные отрасли экономики: проблемы и перспективы развития. № 7. С. 20-26. [Kleimenova E.O., Chulakova A.O. (2014). Economic diversification of single-industry towns due to the development of industrial tourism. Infrastructure Sectors of the Economy: Problems and Development Prospects, 7, 20-26 (in Russian).]

Лысикова О.В. (2014). Индустриальный туризм в городском пространстве: кейсстади Саратова // Лабиринт. Журнал соииально-гуманитарных исследований. № 1. C. 38-48. [Lysikova O.V. (2014). Industrial tourism in urban space: Saratov case study. Labyrinth. Journal of Social and Humanitarian Studies, 1, 38-48 (in Russian).]

Медяник A.B., Тарабановская С.B. (2015). Понятие и роль промышленного туризма в развитии региона // Современные фундаментальные и прикладные исследования. № 1 (16). C. 78-82. [Medyanik A.V., Tarabanovskaya S.V. (2015). The concept and role of industrial tourism in the development of the region. Modern Fundamental and Applied Research, 1 (16), 78-82 (in Russian).]

Никулина Ю.Н. (2015). Роль промышленных экскурсий в становлении конкурентоспособного специалиста / / Экономика и предпринимательство. № 8 (1). C. 589-593. [Nikulina Yu.N. (2015). The role of industrial excursions in the formation of a competitive specialist. Economy and Entrepreneurship, 8 (1), 589 593 (in Russian).] 
Никулина Ю.Н. (2017). Исследование востребованности и перспектив развития промышленного туризма в регионе: взгляд предприятий // Kpeативная экономика. Т. 11. № 8. C. 875-892. DOI: 10.18334/ce.11.8.38204 [Nikulina Yu.N. (2017). Study of demand and prospects of development of industrial tourism in the region: the view of enterprises. Creative Economy, 11 (8), 875-892. DOI: 10.18334/ce.11.8.38204 (in Russian).]

Скляренко С.А., Панченко Т.М., Селиванов И.А., Головенко М.В. (2011). Перспективы развития промышленного туризма в России / / Российское предпринимательство. № 10 (1). C. 146-150. [Sklyarenko S.A., Panchenko T.M., Selivanov I.A., Golovenko M.V. (2011). Prospects for the development of industrial tourism in Russia. Russian Journal of Entrepreneurship, 10 (1), 146150 (in Russian).]

Соломонова Л.В., Нарута Я.С. (2018). Промышленный туризм как фактор взаимодействия вуз - предприятие на территории Приморского края // Карельский научный журнал. Т. 7. № 3 (24). C. 69-72. [Solomonova L.V., Naruta Y.S. (2018). Industrial tourism, as a factor in the interaction of the university - an enterprise in the Primorsky territory. Karelian Scientific Journal, 7, 3 (24), 69-72 (in Russian).]

Тимофеев Н.В. (2014). Концепция развития промышленного туризма как способ повышения экономического благосостояния Санкт-Петербурга (на примере судостроительного кластера) / / Известия Санкт-Петербургского государственного экономического университета. № 2 (86). С. 142-145. [Timofeev N.V. (2014). The concept of industrial tourism development as a way to improve the economic well-being of St. Petersburg (on the example of a shipbuilding cluster). Izvestia Sankt-Peterburgskogo gosudarstvennogo ekonomicheskogo universiteta, 2 (86), 142-145 (in Russian).]

Яшалова Н.Н., Акимова М.А., Рубан Д.А., Бойко С.В., Усова А.В., Мустафаева Э.Р. (2017). Перспективы регионального развития промышленного туризма в свете анализа основных экономических показателей российской туриндустрии // Экономические и соииальные перемены: факты, тендениии, прогноз. Т. 10. № 2. С. 195-213. DOI: 10.15838/esc/2017.2.50.11 [Yashalova N.N., Akimova M.A., Ruban D.A., Boiko S.V., Usova A.V., Mustafaeva E.R. (2017). Prospects for regional development of industrial tourism in view of the analysis of the main economic indicators of Russian tourism industry. Economic and Social Changes: Facts, Trends, Forecast, 10, 2, 195-213. DOI: $10.15838 / \mathrm{esc} / 2017.2 .50 .11$ (in Russian).]

Chow H.-w., Ling G.-J., Yen I-y., Hwang K.-P. (2017). Building brand equity through industrial tourism. Asia Pacific Management Review, 22, 70-79.

Cordeiro J. (2017). A Norma de qualidade e os desafios que se colocam ao turismo industrial. Dos Algarves: A Multidisciplinary e-Journal, 30, 6-17. DOI: 10.18089/ DAMeJ.2017.30.1

Gelbman A. (2007). Tourism in industry in the post-industrial city. Les Mondes Urbains Du Tourisme, 2 (1), 151-162.

Lee C.-F. (2015). An investigation of factors determining industrial tourism attractiveness. Tourism and Hospitality Research, 16 (2), 184-197. DOI: $10.1177 / 1467358415600217$ 
Otgaar A. (2012). Towards a common agenda for the development of industrial tourism. Tourism Management Perspectives, 4, 86-91.

Поступила в редакиию 28.07.2020

Received 28.07.2020

\title{
T.A. Tankieva
}

Tula State University, Tula, Russia

M.V. Ponomareva

Tula State University, Tula, Russia

\section{A study of consumers and the development problems of industrial tourism in the old industrial region (on the example of the Tula region $)^{5}$}

\begin{abstract}
Over the course of the last few decades, there has been a growing interest in industrial tourism as a way to diversify regional economies and establishing a new direction of the territories development. Theoretical scientific literature and existing proposals research showed that such a development of the industrial tourism is based on limited types of production, such as food industry and electric power enterprises, as well as enterprises producing goods attractive to consumers (souvenirs, toys, cars). Experience in the development of industrial tourism shows that city and state authorities can stimulate the development of industrial tourism in the region using the potentials of the enterprises comprising its main economic base. Depending on the degree of interest of producers and possible benefits for the region, there is a need for flexible support of enterprises from other tourism actors. Local educational establishments can assist in building modern tourism products and developing effective marketing strategies. The practical significance of this work lies on the a survey of 564 potential industrial tourism consumers. It revealed rather significant differences in interest of the tourists in organizing and filling programs, depending on gender and age of the respondents.
\end{abstract}

Keywords: industrial tourism, tourism consumers, diversification of activities, potential of the region, industrial excursion.

JEL Classification: M30, R11.

DOI: $10.31737 / 2221-2264-2021-49-1-6$

\footnotetext{
${ }^{5}$ The study is supported by Russian Foundation for Basic Research and the Tula Region in the framework of the scientific project 19-410-710004.
} 